\title{
A Bacitracin-negative Mutant of Bacillus licheniformis Which is Able to Sporulate
}

\author{
By H. I. HAAVIK AND S. THOMASSEN \\ Department of Research and Development, \\ A/S Apothekernes Laboratorium for Specialpraeparater, Oslo, Norway
}

(Received 6 December 1972; revised 6 February 1973)

The formation of peptide antibiotics is frequently associated with the sporulation process of the producer organisms (Bernlohr \& Novelli, I960; Winnick, Lis \& Winnick, I96I; Paulus, 1967; Hurst, 1969). Generally, petide antibiotics are produced after rapid growth and before sporulation (Bodanszky \& Perlman, 1969; Weinberg, 1970).

The peptide antibiotic bacitracin is synthesized by Bacillus licheniformis only under cultural conditions that support spore formation and specific sporulation inhibitors inhibit bacitracin formation (Bernlohr \& Novelli, 1960, 1963).

Investigation of mutants indicates the close connexion between antibiotic synthesis and sporulation (Balassa, 1969; Schaeffer, 1969). Mutants have been isolated which show no antibiotic activity which also produce no spores (Schaeffer, 1967; Schmitt \& Freese, 1968). Mutants unable to sporulate normally can be blocked at different stages in the sporulation process (Young \& Fitz-James, 1959). Mutants which are both antibiotic and sporulation negative are blocked at an early stage, whereas mutants blocked at later stages are found to be non-sporulating antibiotic producers and restoration of antibiotic production by reversion, transduction or transformation restores the ability to sporulate (Hoch \& Spizizen, 1969; Schaeffer, 1969). Schmitt \& Freese (1968) and Schaeffer (1967) conclude that the production of peptide antibiotics is essential for sporulation to reach stage one.

Schaeffer (1969) isolated five partially antibiotic deficient mutants of Bacillus subtilis which are capable of forming spores and suggests that one non-essential antibiotic out of several produced has been lost in these mutants.

Hodgson (1970) postulates that all mutants of Bacillus species which fail to produce antibiotics, also fail to sporulate and he concludes that these peptides are required for a normal sporulation process.

Ray \& Bose (I97I), however, have reported mycobacillin-negative spore-forming mutants of Bacillus subtilis.

We have isolated several bacitracin-negative mutants during selection for higher yielding bacitracin mutants of Bacillus licheniformis. This report describes one of these mutants, SB 319, which is bacitracin-negative and still able to sporulate.

\section{METHODS}

Organisms and mutagenic treatment. The bacitracin-producing strains Bacillus licheniformis $\mathrm{AL}$ and $B$. licheniformis ATCC I071 6 were used as reference strains. Mutants were made from strain AL by u.v. treatment of spores (Philips UV-lamp DD I I5). The dose most frequently used, was $520 \mathrm{erg} / \mathrm{mm}^{2}$ at a rate of $65 \mathrm{erg} / \mathrm{mm}^{2} \mathrm{~s}$.

Media and growth conditions. The medium used for growth and bacitracin production had 
the following composition (g/1000 ml distilled water): Bacto-soytone, 20; Bactopeptone, I0; Bacto-glucose, I0; $\mathrm{K}_{2} \mathrm{SO}_{4}$, I.0; $\mathrm{MnSO}_{4} \mathrm{H}_{2} \mathrm{O}$, 0.0I. The $\mathrm{pH}$ was adjusted to $7^{\circ} 0$ before autoclaving at $\mathrm{I} 2 \mathrm{I}{ }^{\circ} \mathrm{C}$ for $20 \mathrm{~min}$. In this medium strain $\mathrm{AL}$ normally yields about 80 i.u. bacitracin $/ \mathrm{ml}$ in $28 \mathrm{~h}$. Growth occurred in $500 \mathrm{ml}$ Erlenmeyer flasks at $37^{\circ} \mathrm{C}$ at $400 \mathrm{rev} . / \mathrm{min}$ on a New Brunswick rotatory shaker (Model G-53). The sporulation medium used was Bacto-soytone (Io g/l).

Microbiological assay of bacitracin. Bacitracin was determined by an agar-diffusion method according to Dahl et al. (1972). Io $\mathrm{ml}$ of seed agar inoculated with a predetermined concentration of Micrococcus flavus was added directly to the $9 \mathrm{~cm}$ Petri dishes. Six stainless steel cylinders were placed on the surface of the seeded plates by a mechanical dropping device. Three of the cylinders were filled with our working standard of concentration I i.u. bacitracin $/ \mathrm{ml}$. The other three cylinders were filled with the concentration to be determined. The diameters of the zones of inhibition were measured with a Fisher-Lilly zone reader.

Thin-layer chromatography (t.l.c.). Bacitracin was deleted by t.l.c., slightly modified from the method given by Styczyńska, Niemczyk \& Mazoń (I97I). The centrifuged supernatants of fermentation broths ( 2 to $5 \mu \mathrm{l}$ ) were separated on thin-layer plates (Eastman, Silica Gel $6060)$ for $3 \mathrm{~h}$. The solvent used was a mixture of $n$-butanol:acetic acid:water $(4: 1: 2)$. The antibiotic appeared on the chromatograms as a distinct yellow-brown spot after development with ninhydrin. Microbiologically, the antibiotic was identified on chromatograms by overlaying with Micrococcus flavus. By using low concentrations of $M$. flavus in the agar overlay, it was possible to detect as little as $0 \cdot I$ i.u. purified bacitracin $/ \mathrm{ml}$. In this system the bacitracin inhibition zone had a $R_{F}$ value of approximately 0.5 .

Spore count. Spores were counted after heat treatment at $80^{\circ} \mathrm{C}$ for $30 \mathrm{~min}$.

Biochemical tests. Motility was examined in Bacto-Penassay Broth (Difco, Michigan, Detroit, U.S.A.) with $0.4 \%$ agar. Urease production, in Urea Agar Base (Difco) with $2 \%$ urea added. $\mathrm{H}_{2} \mathrm{~S}$ production, in TSI-Agar (Difco) stab cultures. Indole production in casein-peptone $(0.5 \%)$ and $\mathrm{Na}_{2} \mathrm{HPO}_{4} .2 \mathrm{H}_{2} \mathrm{O}(0.2 \%)$. O-F tests were carried out in Hugh and Leifson's medium. Methyl red reaction, in Clark and Lub's medium. Acid production from carbohydrates was examined in Beef extract-Peptone Broth with I \% carbohydrate and $0.002 \%$ Bromthymol blue. The acetyl-methylcarbinol test was carried out in Proteose-peptone $(0.7 \%)$, glucose $(0.5 \%)$ and $\mathrm{NaCl}(0.5 \%)$. Nitrate and nitrite reduction, arginine dehydrolase and gelatinase tests were all carried out in standard preparations.

Assay of intracellular bacitracin. For the assay of intracellular bacitracin, cultures were harvested after about $26 \mathrm{~h}$ of incubation, washed twice in cold saline, and resuspended in a small volume of distilled water. The cells were opened with I \% lyzozyme and the lysate was evaporated to dryness under reduced pressure in a rotavapor. The dried mass was dissolved in $\mathrm{I} \mathrm{ml}$ of ethanol and examined for bacitracin by t.l.c. and subsequent overlaying with Micrococcus flavus.

\section{RESULTS AND DISCUSSION}

Bacitracin production and the degree of sporulation of Bacillus licheniformis AL and the mutant SB 319, are listed in Table I. The two strains show approximately the same degree of sporulation, whereas bacitracin production could not be demonstrated in SB 3 I 9 .

No significant differences in sporulation of the two strains could be demonstrated. They started to sporulate at the same time and at the same rate, beginning normally after about I5 $\mathrm{h}$ of incubation, when sporangia could be seen.

Schmitt \& Freese (1968) described a mutant of Bacillus subtilis which shows 20 times less 
Table 1. Sporulation and bacitracin production in Bacillus licheniformis strain AL and strain SB 3 I9

\begin{tabular}{|c|c|c|c|c|}
\hline \multirow[b]{2}{*}{ Strain } & \multicolumn{3}{|c|}{ Degree of sporulation } & \multirow{2}{*}{$\begin{array}{c}\text { Maximum } \\
\text { bacitracin } \\
\text { titre } \\
\text { (i.u. } / \mathrm{ml} \text { ) }\end{array}$} \\
\hline & $\begin{array}{l}\text { After I6 h } \\
(\%)\end{array}$ & $\begin{array}{c}\text { After } 24 \mathrm{~h} \\
(\%)\end{array}$ & $\begin{array}{c}\text { After } 28 \mathrm{~h} \\
(\%)\end{array}$ & \\
\hline $\mathrm{AL}$ & $0 \cdot I$ & $3 \cdot 5$ & $5 \cdot 0$ & 80 \\
\hline SB 319 & $0 \cdot I$ & $2 \cdot 5$ & $5 \cdot 0$ & n.d. \\
\hline
\end{tabular}

antibiotic activity than the reference strain $B$. subtilis 60015 but still shows normal sporulation. Attempts were therefore made to ascertain if the bacitracin-negative strain, SB 319, could produce small amounts of bacitracin which may be sufficient for sporulation to occur. The bacitracin produced by interesting mutants during selection was usually identified by t.l.c. and subsequent overlaying with Micrococcus flavus. However, by using this technique it was not possible to detect bacitracin production by SB 319, either by ninhydrin development of the chromatograms, or by overlaying with low concentrations of $M$. flavus.

The data show that, if strain SB 319 produces any bacitracin, production must be less than $0 . I$ i.u./ml (the lowest concentration of bacitracin detectable by this analytical method). This amount would, however, be negligible when compared to both the 80 i.u. bacitracin $/ \mathrm{ml}$ produced by the reference strain AL and the 50 i.u. bacitracin/ml usually produced by strain ATCC 10716.

It was possible that SB 319 produced bacitracin but did not excrete it. The cells were therefore disrupted with lyzozyme, and the cell content was examined for bacitracin as described under Methods. No bacitracin was detected in SB 319 by this technique. When cells of strain AL were treated in the same manner, bacitracin was detected. This indicates that the lack of bacitracin in cultures of SB 319 is not due to a defect in excretion.

Strain AL and SB3I9 showed the same growth rate and identical morphology during all stages of growth in the production medium. Both showed growth at $56^{\circ} \mathrm{C}$, in $7 \% \mathrm{NaCl}$ and anaerobic growth. In an O-F test both organisms fermented glucose. The two strains also showed identical reactions in several other biochemical tests. The following tests were positive: Gram reaction, growth in Cosers citrate medium, nitrate reduction, arginine dehydrolase, acetylmethylcarbinol production, acid production after $24 \mathrm{~h}$ from: starch, glucose, sucrose, arabinose, mannitol, sorbitol.

The following tests were negative: $\mathrm{H}_{2} \mathrm{~S}$ production, nitrite reduction, urease, gelatinase $22{ }^{\circ} \mathrm{C}$, indole production, methyl red reaction, acid production after $24 \mathrm{~h}$ from: lactose, xylose, raffinose. Both strains showed motility.

The data show that SB 319 is a mutant of Bacillus licheniformis strain AL, and that this mutant is able to sporulate, although it is bacitracin-negative. The existence of such mutants, rules out a direct role for the peptide antibiotic bacitracin in the formation of spores in this species.

The authors wish to thank Mr T. Höyland, Director of Research and Development, for his support in this work, Dr H. P. Throndsen for valuable discussion in preparing the text, and Mrs Anne Gjertsen, Mrs Eva Gustavsson and Mrs Linda Horn for skilled technical assistance. 


\section{REFERENCES}

BALASSA, G. (I969). Biochemical genetics of bacterial sporulation. I. Unidirectional pleiotropic interactions among genes controlling sporulation in Bacillus subtilis. Molecular and General Genetics 104, 73-103.

Bernlohr, R. W. \& Novelli, G. D. (1960). Some characteristics of bacitracin production by Bacillus licheniformis. Archives of Biochemistry and Biophysics 87, 232-238.

Bernlohr, R. W. \& Novelli, G. D. (I963). Bacitracin biosynthesis and spore formation: the physiological role of an antibiotic. Archives of Biochemistry and Biophysics 103, 94-104.

Bodanszky, M. \& Perlman, D. (1969). Peptide antibiotics. Science, New York 163, 352-358.

Dahl, S. G., WaAler, T., Thomassen, S., Öystese, B. \& Höyland, T. (1972). Testing error in the screening of bacitracin producing strains for high yielding mutants. Pharmaceutica acta helvetiae 47, 424-432.

Hoch, J. A. \& SpIzizen, J. (I969). In Spores IV, pp. I I2-I 19. Edited by L. L. Campbell. Washington, D.C.: American Society for Microbiology.

Hodgson, B. (1970). Possible roles for antibiotics and other biologically active peptides at specific stages during sporulation of Bacillaceae. Journal of Theoretical Biology 30, I I-I 19.

Hurst, A. (1969). In The Bacterial Spore, pp. I67-I82. Edited by G. W. Gould and A. Hurst. London and New York: Academic Press.

Paulus, H. (1967). In Antibiotics II, pp. 254-267. Edited by D. Gottlieb and P. D. Shaw. Heidelberg and New York: Springer Verlag Berlin.

RAY, B. \& Bose, S. K. (I971). Polypeptide antibiotic-negative sporeformer mutants of Bacillus subtilis. Journal of General and Applied Microbiology 17, 49 I-498.

SCHAEFFER, P. (1967). Asporogenous mutants of Bacillus subtilis Marburg. Folia microbiologica 12, 29I-296.

SCHAEFFER, P. (1969). Sporulation and the production of antibiotics, exoenzymes, and exotoxins. Bacteriological Reviews 33, 48-7I.

SCHMitT, R. \& Freese, E. (1968). Curing of a sporulation mutant and antibiotic activity of Bacillus subtilis. Journal of Bacteriology 96, 1255-1265.

STYCZYŃSKa, D., NiEMCZYK, H. \& MAZOŃ, M. (I97I). Stimulation of bacitracin production in the mixed cultures of Bacillus subtilis and Pseudomonas sp. Acta microbiologica polonica B 3, 69-77.

WeInBERG, E. D. (1970). Biosynthesis of secondary metabolites: roles of trace metals. Advances in Microbial Physiology 4, I-44.

WINNICK, R. E., LIs, H. \& WINNICK, T. (I96I). Biosynthesis of Gramicidin S. I. General characteristics of the process in growing cultures of Bacillus brevis. Biochimica et biophysica acta 49, 45I-462.

Young, I. E. \& Fitz-JAmes, P. C. (1959). Chemical and morphological studies of bacterial spore formation. I. The formation of spores in Bacillus cereus. Journal of Biophysical and Biochemical Cytology 6, 467-481. 